\title{
下部尿路疾患と尿分泌型 IgA
}

$\begin{array}{ccccc} & \text { 長 } & \text { 田 } & \text { 尚 夫 } \\ \text { 聖マリアンナ医科大学泌尿器科教室 } & \text { 井 } & \text { 上 } & \text { 武 夫 } \\ \text { (主任: 并上武夫教授) } & \text { 平 } & \text { 野 } & \text { 昭 } & \text { 彦 }\end{array}$

\section{URINARY SECRETORY IgA IN LOWER URINARY TRACT DISEASES}

Takao Osada, Takeo Inoue and Akihiko Hirano

Department of Urology, St. Marianna University, School of Medicine

(Director: Prof. T. Inoue)

In order to investigate the local immune defense mechanism of urinary tract disease, secretory IgA, which seemed to participate these local defense system, was measured in the urine of patient with lower urinary tract disease. Urinary IgA, IgE, IgG and IgM were estimated simultanously. The single radial immunodiffusion was used for all of the measurement.

The study was done in the patients with acute cystitis, chronic cystitis, acute pyelonephritis, non-infected urinary tract disease and normal adult.

1) Urinary secretory IgA levels showed a high value in most patients with cystitis, both acute and chronic form, but not in acute pyelonephritis.

2) In all of patients with non-infected urinary tract disease, urinary secretory IgA levels were below normal.

3) Urinary secretory IgA levels, in patients with urinary tract tumor, did not show a high value.

4) Furthermore, in urinary $\operatorname{IgA}, \operatorname{IgE}, \operatorname{IgG}$ and $\operatorname{IgM}$, there was no statistical difference among each group, except IgG which was increased in some cases of urinary tract infection, especially chronic cystitis.

From these findings, we suggest that urinary secretory IgA level reflects the antibody response of the lower urinary tract infection.

\section{緒言}

尿路感染症の発生病理に打いて, 上行性感染, 血行性 感染, リンパ行性感染の 3 経路が考えられる. そのう ち, 最も頻度が高く主要な役割をもつているものは上行 性感染であることは周知の事実である. 一般に外尿道口 から尿道にかけて多数の細菌にさらされているにるかか わらず, 膀胱尿は通常無菌である. 冬れゆ光, 細菌が外 界から侵入して上行する際に，尿道扣よび膀脱が一つの 関門となつていると考えることが出来る.

Cox \& Hinman ${ }^{1)}$ は正常尿路に接種した 細菌が急速 に消失することを認め, intrinsic bladder defense mechanism といら概念を提唱した.

われわれは，膀脂粘膜には 細菌侵入に 対する 関門と しての作用があるかどうか，またあるとすればその機
序はどのようなものかを解明したいと考光た． intrinsic bladder defense mechanism $は$ immunologic system $の$ 別 の表現であるという立場にたつて，局所性に合成分泌さ れた免疫グロブリンの重要性を想定し, 尿免度グロブリ ンが局所免疫防禦機構に関与するであろらと考兵た。 そ こで, 下部尿路疾患に打ける尿免疫グロブリン，特に分 泌型 IgA を調べ，その役割を検討した。

\section{試料ならびに方法}

(対象)

聖マリアンナ医科大学 (旧称東洋医科大学) 東横病院 泌尿器科に受診した患者を対象とした. 症例数は51例， 55検体である。

これらを，尿路に異常を認めない正常群，単純性細菌 性急性膀胱炎群, 基礎疾患が存在している慢性膀胼炎 
群, 単純性細菌性急性腎孟腎炎群，いづれにも属せず下 部尿路感染をともなわない泌尿器疾患をその他の疾患群 として，5群に分類した.

正常群： 7 例， 8 検体（1 例は 3 力月間隔で 2 回採 尿）

急性膀胱炎群 : 11 例

慢性膀脱炎群：13例

急性腎孟腎炎群 : 5 例， 7 検体（1 例は 1 週間隔で 3 回採尿)

その他の疾患群 : 15 例, 16 検体（1 例は 1 週間隔で 2 回採尿）

正常群の内訳は, 正常者 3 例 4 検体, 南丸腫瘍 1 例, 停 留辠丸 1 例, 類宦官症 1 例, Klinefelter 症候群 1 例 で ある. 慢性膀脱炎群の基礎疾患の内訳は, 膀胱癌 3 例, 膀脂結石 1 例, 膀胱瘦 3 例, 神経因性膀胱 3 例, 前立 腺肥大症 3 例である. その他の疾患群の内訳は, 腎癌 1 例, 腎孟癌 1 例, 小児慢性腎孟腎炎 2 例 3 検体, 水腎症 1 例, SLE 1 例, 膀胼癌 7 例, Scheele 氏迴腸環膀胱吻 合術後10年経過症例 1 例, 前立腺炎後遺症 1 例である.

な怙，小児慢性腎㙉腎炎 2 例を除いて成人症例であ り, 性別では, 男32例, 女19例である.

（検体の採取打よび処理方法）

尿蛋白の分析を括こならためには，尿蛋白をほぼ血清 蛋白濃度にまで濃縮する必要がある. とくに健康人尿 や，下部尿路疾患々者尿の蛋白排泄量はごくわずかであ り，微量の尿蛋白分析を抽こなうためにはまづ正確で高 度の尿濃縮操作が 要求される.われわれは, Pollak ${ }^{2)}$, Kaufman $^{3)}$, Uehling'), Feldman ${ }^{5)}$ らの 方法を参考にし て，次のように尿を処理して検体を作製した。

1）採尿：原則として24時間尿を採取した．ただし外 来通院患者は24時間尿を採取出来ないものが多く適当量 を使用した. 肉眼的血尿をもつた症例は対象から除外し た. 少量のトルエン添加後, 冷暗所に保存し, 寸みやか に次の操作を行なつた.

2）遠沈：血球，上皮，細菌“結晶などをとり除くた め，3000rpm，15分間遠沈した.

3）濾過：遠沈して得られた上清を No. 2 滤紙で濾過 した.

4）透析濃縮：セルローズ・チューブ（Visking 製）

に濾液を入れ，ポリエチレン・グリコール6000を用いて 渗透圧濃縮と透析をかねて扔こなつた。この濃縮液をコ ロヂオン・バッグ (Membranfilter 製)を通して陰圧を 作用させる限外滤過法により, 血清蛋白濃度（6〜7 g/dl）になるよう濃縮した.

5）遠沈：濃縮尿を3000rpm，15分間遠沈し，得られ た上清を検体とした.

6）保存：検体 1 容に対し，10\%室化ナトリウム溶液 を $1 / 100$ 容加兄, 冷凍保存した.

なお，濃縮率は22〜 786倍であつた，当然被検尿の蛋 白排泄量によつて異り, 前述の血清蛋白濃度を最終目標 として濃縮した。この濃縮率はBienenstock \& Tomasi ${ }^{6}$, Uehling \& Steihm ${ }^{4)}$, Kaufman ${ }^{3)}$ らのものと略一致して おり, 加藤”によれば推計学的に濃縮による誤差はほと んど認められなかつたという。

（測定した免疫グロブリンの種類） 分泌型 IgA をはじめ，IgA，IgE，IgG，IgM である.

（測定方法）

Mancini および Heremans による一元平板免疫拡散 法の原法に従つた. すなわち，特異抗体を含むアガロー スゲル平板を作製し，小孔をあけ検体を注入すると，検 体が拡散し小孔のまわりに抗原抗体反応に上る沈降輪を 形成する. この沈降輪の面積は抗原濃度と比例関係にあ るので，抗原量既知の物質を用いて検量曲線を作つてお けば，検体の沈降輪に対応する蛋白濃度を求めることが 出来る. その操作は次の通りである.

1）アガロースゲル平板の作製：アカロース $1.2 \mathrm{~g}$, ベロナール緩衝液（pH 8.6） $50 \mathrm{ml}$, 精製水 $50 \mathrm{ml}$ にッウ

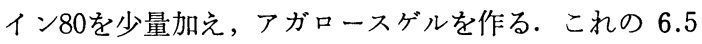
$\mathrm{g}$ に後述する特異抗血清を $0.1 \sim 0.5 \mathrm{ml}$ 混和して平板 を作製した. $2 \mathrm{~cm}$ の間隔をおいて直径 $2 \mathrm{~mm}$ の小をあけ た.

2）後述する 既知濃度抗原の $3 \sim 4$ 段階希釈液を作 る.これは検量曲線作製用である.

3） マイクロシリンジを用いて2)の抗原液を $2 \mu 1$ づ つ平板小孔に注入する. 次いで検体を同様な操作で 2 $\mu 1$ 注入する.

4）容器のふたをして乾燥しないよう室温で48時間水 平に静置する。

5）観察箱を用い，生じた沈降輪の直径をスケールで 測定する.

6）抗原量を横軸に，沈降輪の直径の 2 乗を縦軸に目 盛り，検量曲線を作製する.

7）検体の沈降輪直径の 2 乗を検量曲線上飞求め, これから検体の免度グロブリン濃度を求めることが出来 る. そして被検尿からの濃縮率から換算して被検尿の免 疫グロブリン濃度を計算する。 
図 1 Ouchterlony test
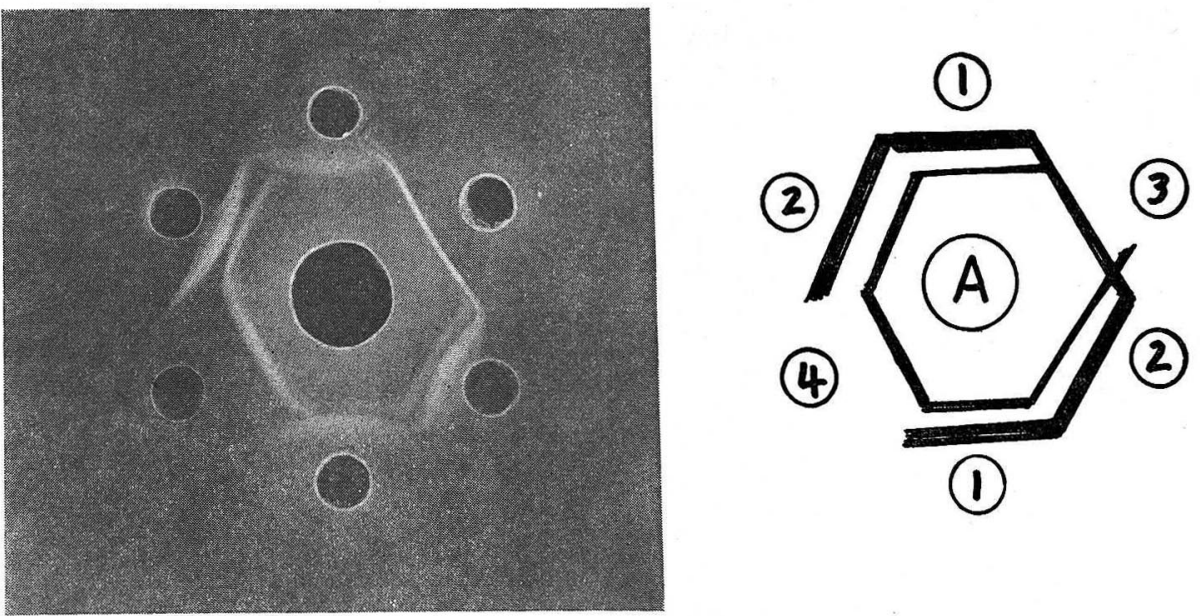

Antiserum: (A) specific anti-colostral IgA

Antigen: (1) sample

(2) human colostrum

(3) normal human serum

(4) free secretory piece purified from human colostrum

なお，分泌型 IgA 測定のために使用した特異抗血清 は Behringwerk 製 Anti-Human-Colostrum-Serum で, Human-Colostrum を躳に投与して得られた抗血清を一 旦全人血清に吸収させて 作製したもので，分泌型 IgA の secretory piece に対して特異的である. したがつて secretory piece のない血清曲来の IgA とは免疫学的な 性質は共有していない。また IgA，IgE，IgG，IgM 測 定のために使用した特異抗血清は Behringwerk 製 AntiIgA-Globulin, Anti-IgE-Globulin, Anti-IgG-Globulin, Anti-IgM-Globulin である. そして抗原としては，分泌型 IgA は後述する健康人尿濃縮液を用い，IgA, IgE, IgG, IgMはいづれも Behringwerk 製 Standard-Human-Serum を用いた。

\section{成 績}

I．尿分泌型 IgA の同定

健康人尿を上記の方法にしたがつて処理した濃縮尿検 体を抗原として Anti-Human-Colostrum Serum を抗血 清として兔疫拡散法を和こなつたところ, 沈降線を生 じた。 そこで健康人尿に分泌型 IgA の存在を考えて Ouchterlony test を括こなつた. 金沢大学医学部小児科 学教室加藤彰一博士の御好意により同定していただいた ものが図 1 で, 左はその写真, 右はシェーマである. 健 康人濃縮尿検体は抗初乳 IgA 特異抗血清により 2 本の
沈降線を生じ, 抗原孔に近い沈降線は分泌型 IgA で，抗 血清孔に近い沈降線は free secretory piece の沈降線で ある. すなわち，健康人尿に分泌型 IgA およびsecretory piece が検出された。

また，この健康人濃縮尿の分泌型 IgA 濃度を同博士 の御好意により測定した. 測定法はsingle radial immunodiffusion で，抗血清は IgA 骨䯣腫蛋白を用いて作製 した家鬼抗 IgA，標準抗原はヒト初乳 IgA である.

この研究に使用した分泌型 IgA 検量曲線作製用の標 準抗原は, この既知濃度の健康人濃縮尿検体を用いた。

II . 尿免疫グロブリン測定成績（表 1〜 5)

われわれの打こなつた一元平板免疫拡散法による尿免 疫グロプリンの最小検出濃度は, 濃縮尿検体濃度としてて 次の通りである. 分泌型 IgA は $5 \mathrm{mg} / \mathrm{dl} ， （ 100$ 倍濃縮尿 検体として被検尿濃度は $0.05 \mathrm{mg} / \mathrm{dl} ， 500$ 倍で $0.01 \mathrm{mg} / \mathrm{dl}$ ， となる. 以下同様に計算される). IgA $5 \mathrm{mg} / \mathrm{dl}, \operatorname{IgE} 0.05$ $\mathrm{mg} / \mathrm{dl}, \mathrm{IgG} 5 \mathrm{mg} / \mathrm{dl}, \mathrm{IgM} 7 \mathrm{mg} / \mathrm{dl}$ である. この值以下の 濃度はすべて（一）として表現した.

また，急性膀脱炎患者では24時間尿を採取出来ないる のが多かつたので，24時間排出量ではなく，被検尿の免 疫グロブリン濃度で比較することとした。

(1) 分泌型 IgA

正常群： 8 検体中 3 検体で定量可能濃度で，それぞ 
表 1 正常群

\begin{tabular}{c|c|c|c|c|c|c|c}
\hline 症 例 番 号 & 性 & 年 令 & 分泌型 IgA & IgA & IgG & IgM & IgE \\
\hline $\mathrm{A}-1-\mathbf{a}$ & $\hat{0}$ & 41 & 0.36 & $(-)$ & 0.69 & $(-)$ & $(-)$ \\
\hline$-1-\mathbf{b}$ & $\hat{0}$ & 41 & 0.16 & 0.41 & 0.31 & $(-)$ & $(-)$ \\
\hline-2 & $\hat{0}$ & 31 & $(-)$ & $(-)$ & 0.10 & $(-)$ & $(-)$ \\
\hline-3 & $\hat{\delta}$ & 20 & 0.09 & 0.33 & 0.50 & $(-)$ & $(-)$ \\
\hline-4 & $\hat{0}$ & 40 & $(-)$ & 0.05 & $(-)$ & $(-)$ & $(-)$ \\
\hline-5 & $\hat{0}$ & 29 & $(-)$ & $(-)$ & 0.08 & $(-)$ & $(-)$ \\
\hline-6 & $\hat{0}$ & 23 & $(-)$ & $(-)$ & $(-)$ & $(-)$ & $(-)$ \\
\hline-7 & $\hat{\delta}$ & 20 & $(-)$ & $(-)$ & 0.04 & $(-)$ & $(-)$ \\
\hline
\end{tabular}

表 2 急性膀胱炎群

\begin{tabular}{|c|c|c|c|c|c|c|c|}
\hline 症例番 号 & 性 & 年 令 & 分泌型 IgA & IgA & IgG & $\operatorname{IgM}$ & $\operatorname{IgE}$ \\
\hline$B-1$ & $\hat{0}$ & 34 & 1.95 & 0.92 & 6.53 & $(-)$ & $(-)$ \\
\hline-2 & 우 & 23 & 1.17 & 0.91 & 1.72 & $(-)$ & $(-)$ \\
\hline-3 & 우 & 32 & 0.23 & 0.36 & 1.35 & $(-)$ & $(-)$ \\
\hline-4 & 우 & 22 & $(-)$ & 0.46 & 1.40 & $(-)$ & $(-)$ \\
\hline-5 & 우 & 41 & 0.14 & & & & \\
\hline-6 & 우 & 52 & 0.50 & 0.22 & 0.32 & 0.11 & $(-)$ \\
\hline-7 & 우 & 72 & $(-)$ & 0.37 & 0.77 & $(-)$ & $(-)$ \\
\hline-8 & 우 & 33 & $(-)$ & 0.18 & 0.12 & $(-)$ & $(-)$ \\
\hline-9 & 우 & 51 & $(-)$ & 0.54 & 0.57 & $(-)$ & $(-)$ \\
\hline-10 & 우 & 34 & 2.29 & 1.72 & 3.62 & $(-)$ & $(-)$ \\
\hline-11 & 우 & 33 & $(-)$ & 0.04 & $(-)$ & $(-)$ & $(-)$ \\
\hline
\end{tabular}

表 3 慢性膀胱炎群

\begin{tabular}{|c|c|c|c|c|c|c|c|c|}
\hline 症 例 番 号 & 性 & 年令 & 基 礎 疾 患 & 分泌型 IgA & $\operatorname{IgA}$ & IgG & IgM & $\operatorname{IgE}$ \\
\hline $\mathrm{C}-1$ & 우 & 73 & 膀 胱 癌 & $(-)$ & 2.50 & 11.20 & $(-)$ & \\
\hline-2 & $\hat{0}$ & 72 & 膀 胱 癌 & 0.11 & 1.13 & 12.66 & $(-)$ & $(-)$ \\
\hline-3 & $\hat{0}$ & 73 & 膀 胱 癌 & 0.34 & 0.48 & 2.76 & $(-)$ & $(-)$ \\
\hline-4 & $\hat{0}$ & 49 & 膀 胱 結 石 & 0.13 & 0.27 & 0.24 & $(-)$ & $(-)$ \\
\hline-5 & $\hat{\delta}$ & 46 & 膀 胱 瘻 & 1.37 & 2.77 & 11.67 & $(-)$ & $(-)$ \\
\hline-6 & $\hat{0}$ & 22 & 膀 脱 瘦 & 1.11 & 1.16 & 1.60 & 1.12 & $(-)$ \\
\hline-7 & $\hat{0}$ & 21 & 脂 瘦 & 0.64 & 0.72 & 2.51 & $(-)$ & $(-)$ \\
\hline-8 & 우 & 38 & 神経因性膀胱 & $(-)$ & 0.11 & 0.73 & $(-)$ & \\
\hline-9 & $\hat{0}$ & 63 & 神経因性膀胱 & 0.34 & 0.16 & 2.55 & $(-)$ & $(-)$ \\
\hline-10 & $\hat{0}$ & 21 & 神経因性膀胱 & 0.21 & 0.18 & 1.06 & $(-)$ & $(-)$ \\
\hline-11 & $\hat{\delta}$ & 67 & 前立腺肥大症 & 0.94 & 4.20 & 16.85 & 4.30 & $(-)$ \\
\hline-12 & $\hat{0}$ & 88 & 前立腺肥大症 & $(-)$ & 0.44 & 1.86 & $(-)$ & $(-)$ \\
\hline-13 & $\hat{o}$ & 68 & 前立腺肥大症 & 0.34 & 1.13 & 4.01 & $(-)$ & $(-)$ \\
\hline
\end{tabular}


裴 4 急性䝳孟腎炎群

\begin{tabular}{|c|c|c|c|c|c|c|c|}
\hline 症 例 番 号 & 性 & 年 令 & 分泌型 IgA & $\operatorname{IgA}$ & IgG & $\operatorname{IgM}$ & $\operatorname{IgE}$ \\
\hline $\mathrm{D}-1-\mathrm{a}$ & P & 51 & $(-)$ & 0.10 & 0.19 & $(-)$ & $(-)$ \\
\hline$-1-b$ & P & 51 & $(-)$ & 0.55 & 0.29 & $(-)$ & $(-)$ \\
\hline$-1-c$ & $?$ & 51 & $(-)$ & 0.46 & 0.75 & $(-)$ & $(-)$ \\
\hline-2 & P & 27 & 0.18 & 4.38 & 0.98 & $(-)$ & $(-)$ \\
\hline-3 & 우 & 45 & $(-)$ & 0.42 & 0.53 & $(-)$ & $(-)$ \\
\hline-4 & $\hat{o}$ & 43 & 0.12 & 0.09 & 0.38 & 0.23 & $(-)$ \\
\hline-5 & 우 & 59 & $(-)$ & 0.35 & 2.10 & 0.39 & $(-)$ \\
\hline
\end{tabular}

表 5 その他の疾患群

\begin{tabular}{|c|c|c|c|c|c|c|c|c|c|c|}
\hline 症 例 番 号 & 性 & 年令 & 疾 & 患 & 名 & 分泌型 IgA & IgA & IgG & $\operatorname{IgM}$ & $\operatorname{IgE}$ \\
\hline$E-1$ & $\hat{\delta}$ & 61 & 腎 & & 癌 & $(-)$ & 0.03 & 0.15 & $(-)$ & $(-)$ \\
\hline-2 & 今 & 66 & 腎 & 杰 & 癌 & $(-)$ & $(-)$ & 0.10 & $(-)$ & $(-)$ \\
\hline-3 & $\hat{\mathrm{O}}$ & 3 & 慢捗 & 慜孟䇛 & & $(-)$ & $(-)$ & 0.16 & $(-)$ & $(-)$ \\
\hline$-4-\mathbf{a}$ & $\hat{s}$ & 6 & 慢怕 & 笡盂腎 & & $(-)$ & 0.18 & 0.27 & $(-)$ & $(-)$ \\
\hline$-4-b$ & 3 & 6 & 慢性 & 限昷留 & & $(-)$ & 0.40 & 0.21 & $(-)$ & $(-)$ \\
\hline-5 & $\hat{0}$ & 22 & 水 & 堅 & 症 & $(-)$ & 0.46 & 0.83 & 0.13 & $(-)$ \\
\hline-6 & P & 44 & $\mathrm{~S}$ & $\mathrm{~L}$ & $\mathrm{E}$ & $(-)$ & 1.05 & 7.06 & $(-)$ & $(-)$ \\
\hline-7 & $\hat{0}$ & 80 & 勝 & 胱 & 粕 & 0.06 & 0.34 & 0.28 & $(-)$ & $(-)$ \\
\hline-8 & P & 55 & 膀 & 胱 & 演 & $(-)$ & 0.07 & 0.96 & $(-)$ & $(-)$ \\
\hline-9 & 웅 & 77 & 膀 & 脱 & 癌 & $(-)$ & $(-)$ & 0.03 & $(-)$ & $(-)$ \\
\hline-10 & $\hat{3}$ & 63 & 䧛 & 胱 & 潅 & $(-)$ & $(-)$ & $(-)$ & $(-)$ & $(-)$ \\
\hline-11 & $\hat{0}$ & 75 & 膀 & 胱 & 癌 & $(-)$ & 0.03 & 0.09 & $(-)$ & $(-)$ \\
\hline-12 & P & 65 & 膀 & 胱 & 癌 & $(-)$ & 0.01 & 0.07 & $(-)$ & $(-)$ \\
\hline-13 & $\hat{0}$ & 43 & 腾 & 脱: & & $(-)$ & $(-)$ & 0.05 & $(-)$ & $(-)$ \\
\hline-14 & $\hat{\delta}$ & 55 & 超 & 環謪 & & 0.09 & 0.23 & 0.24 & $(-)$ & $(-)$ \\
\hline-15 & 古 & 23 & & 前立腸 & & $(-)$ & $(-)$ & $(-)$ & $(-)$ & $(-)$ \\
\hline
\end{tabular}

れ, $0.36,0.16,0.09 \mathrm{mg} / \mathrm{dl}$ であり, 残る4検体は（一) であつた.

急性膀腅炎群：11検体中 6 検体が定量可能濃度で，そ

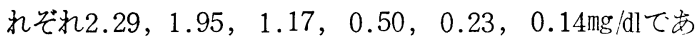
り，残る 5 検体は（一）であつた.

慢性膀胱炎群：13検体中10検体が定量可能濃度で，元 れぞれ1.37，1.13，0.94，0.64，0.34，0.34，0.34， $0.21,0.13,0.11 \mathrm{mg} / \mathrm{dl}$ であり, 残る 3 検体は（一）であ った.

急性腎孟腎炎群： 7 検体中 2 検体が定量可能濃度で, それぞれ0.18，0.12m/dal゙あり，残る 5 検体は（一）で あつた

その他の疾患群: 13 検体中 2 検体が定量可能擃度で， それぞれ，0.09，0.06mg/dlであり，残る11検体は（一) であつた。
成人健康人尿の分泌型 $\operatorname{IgA}$ 值は，尿分泌型 IgA に 関する研究が少なく，文献も散見されるにとどまり，乙 かもバラッキがあるため，一定の值を示すことが難かし い. 年令的にみると，尿分泌型 IgA 濃度や24時間尿排 出值について加藤" 又られず成人平均值に澾すると報告，性別に関しては， Uehling \& Steihm ${ }^{4)}$ は尿免疫グロブリン值の 異女差は 恐められなからたと述べ, Bienenstock \& Tomasi ${ }^{6)}$ の 成績でも尿分泌型 IgA の平均值は男女差がみられてい ない，一方，尿分泌型 IgA 值については, Salmon ${ }^{8)} ら$ は $0.04 \mathrm{mg} / \mathrm{dl}$, Bienenstock \& Tomasi $^{6)}$ は $1.1 \mathrm{mg} / 24$ 時 間, 加藤 ${ }^{2)}$ 《 $0.14 \mathrm{mg} / \mathrm{dl}, 1.56 \mathrm{mg} / 24$ 時間といらのが文献的 にみた正常值である.いま， $0.2 \mathrm{mg} / \mathrm{dl}$ 以上を異常高値と すれば，正常群では 8 検体中 1 例，すなわち $1 / 8$ ，急性膀 胱炎群では $5 / 11$, 慢性膀胱炎群では $8 / 23$, 急性腎孟腎炎群 
図 2 分泌型 IgA

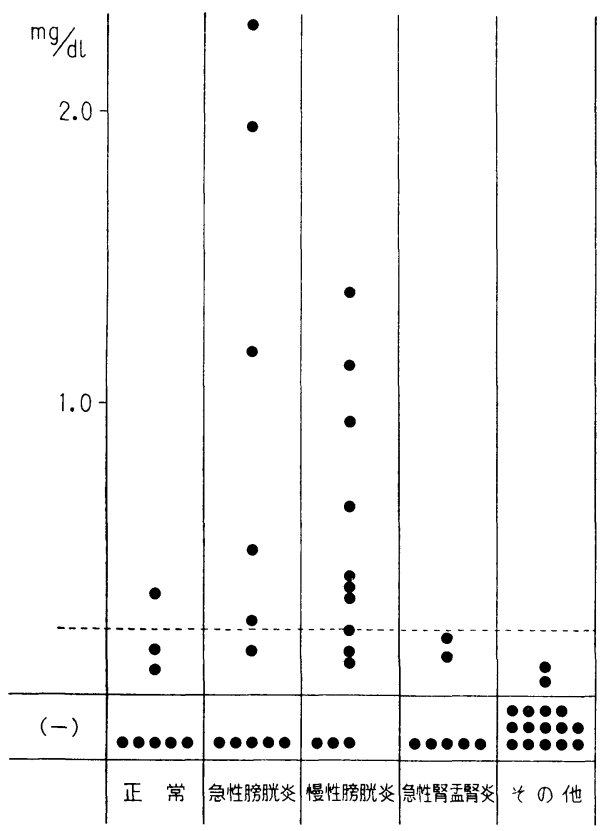

$\%$, その他の疾患群では $/ 13$ である. すなわち, 正常群 の 1 例を除けば, 異常高値を示したものは急性および慢 性膀朕炎群のみである（図 2).このことは, 尿分泌型 IgA が膀胱感染と関聠していることが明らかとなつた.

対象症例のらち, 尿路腫瘍が12例あり, 腎癌 1 , 腎盂 癌 1 , 膀脱癌10である. 尿路感染症を合併していた 2 例 を含めて尿分泌型 IgA の異常高值は 1 例も認めなかつ た.このなかには手術不能であつた進行性膀胼癌の 2 例 が含まれている. 寸なわち，尿路腫瘍と尿分泌型 IgA とは無関係であつた.

(2) $\operatorname{IgA}$

急性膀脂炎群, 慢性膀胱炎群, 急性腎孟腎炎群のうち 少数例のみが高值を示していた. いいかえれば, 高值を 示したものは炎症性疾患群の若干例であつた. しかし， 疾患群の間に有意差は認めなかつた（図 3 ）.

(3) $\operatorname{IgE}$

各群ともすべて（一）であつた.

(4) IgG

その他の疾患群中の SLE の1例を除いて, 高值を示 したものは急性膀脱炎群および慢性膀胱炎群のなかに多 かつた・急性腎雷腎群のなかにも軽度上昇をみたもの もあつた、いいかえれば，炎症性疾患に高値を示すもの
図 3 IgA

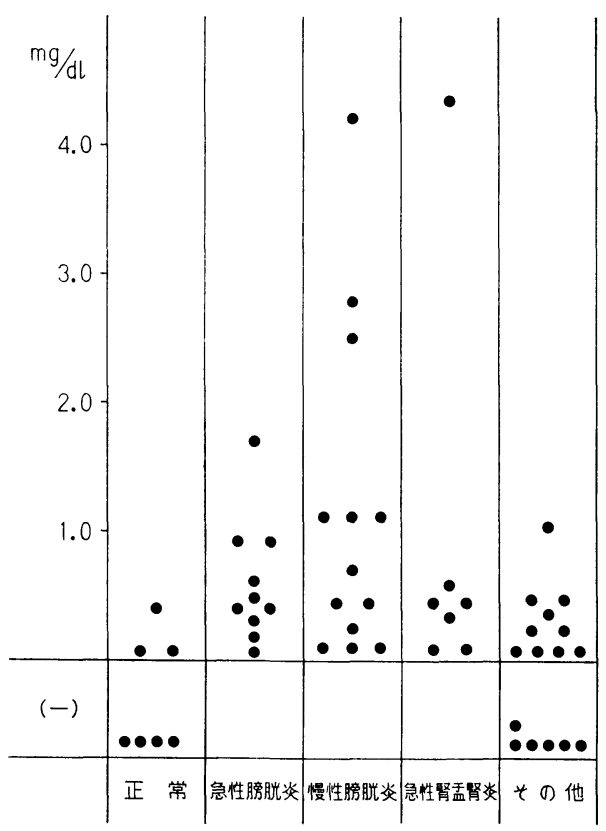

図 4 IgG

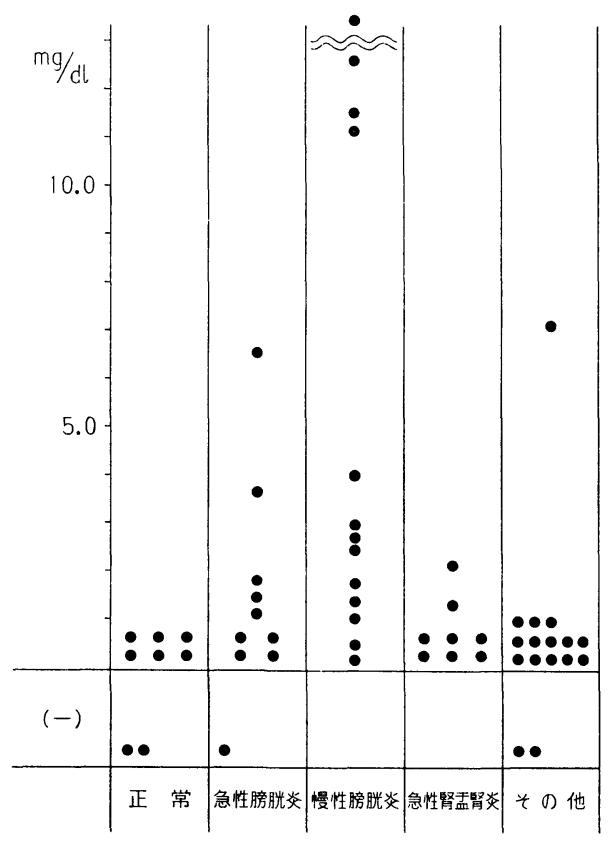

が多く，とくに著明な上昇をみたものは慢性膀胼炎群の 症例であつた（図 4 ）。 
困 5 IgM

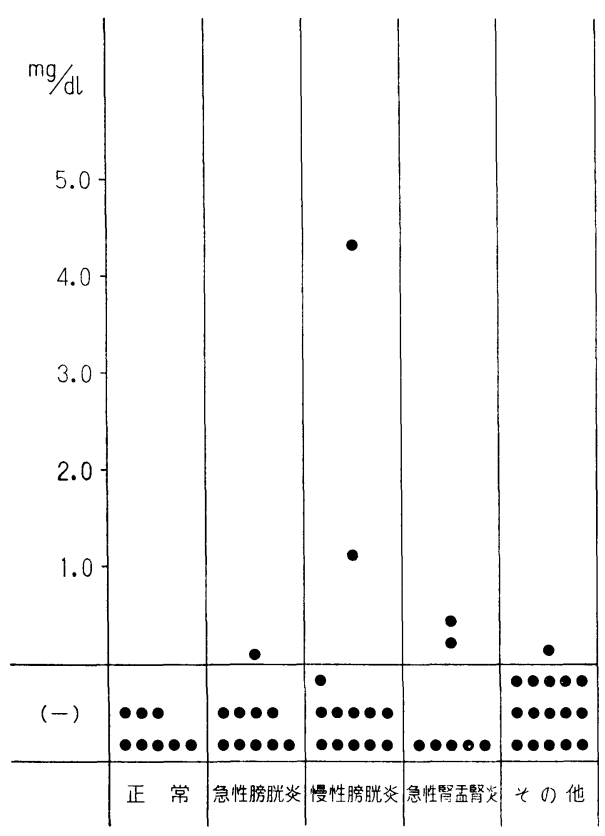

(5) IgM

正常群を除いて, 各群とも $1 \sim 2$ 例の少数に検出され たが，殆んどの症例は（一）であつた（図 5$)$.

\section{考按}

感染は微生物と宿主との相互関係において成立し，さ らに関聠した諸因子により, 発症, 悪化 治癒などの経 過に大きな差異が生じる. 近年, 微生物側の研究に関し ては著しい進歩がみられるが, 宿主側の因子の研究, 特 に防禦機構に関しては未解決のまま残されている分野が 多い.

正常な膀胼粘膜には内因性に防禦機構があることは多 くの実験により証明されているが119110111112)13)，そのメ カニズムは未だ明らかではない，膀脱防禦機構に打ける 免疫はのたす役割や，免疫グロブリンの意義についても 推定の域を脱していない，最近，尿の分泌型 IgA と尿 路の局所免疫との関係がクローズアップされて来た.

\section{(分泌型 $\operatorname{IgA}$ )}

近年, 分泌液中の免疫グロブリンの大部分が IgA か らなるという重要な知見が明らかになつている.すなわ ち, 涙, 唾液, 鼻汁, 初乳, 呼吸器分泌液, 消化管分泌 液などに存在する抗体は，おるに IgA 性抗体からなつ ている.この分泌液中に存在する IgA はsecretory piece を中心として結合した dimer として分泌され，物理化学
的にも免疫学的にも血清 IgA と区別される.これを分 泌型 IgA と呼ばれ, 分泌腺粘膜下組織の lamina propria の形質細胞で局所性に合成され, 分泌されるもので血清 IgAから移行したものではない。

一方, 唾液腺, 乳腺, 呼吸器粘膜, 消化管粘膜など は，局所免疫機構が存在している場として知られてお り, 分泌液中の分泌型 IgA が粘膜を感染から防禦する 働きをしているものと考えられている。いいかえれば， 分泌型 IgA が局所免疫機構と関聠があるとされてい る. そして局所免疫機構に関与していることを証明する 事実が明らかにされている.

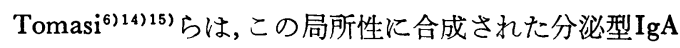
が尿中にあることを認め, また膀胱分泌液中にも存在し ていることを証明した．これは膀脱において分泌型 IgA が局所性に 産生することを示すものである．Feldman ${ }^{5)}$ らは Dysfunctionized bladder の膀羘分泌液を詳細に検 索し, その蛋白構成のパターンは他の粘膜性分泌夜のパ ターンと一致し，分泌型 IgA も全く同一であることを 証明した. そしてこれは単なる血清の漏出ではないと している. Hong も同じょらな膀脱の洗深液から分泌型

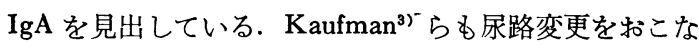
つた患者の膀胱内に分泌型 IgA の存在を証明した。こ らした事実は，膀胱粘膜は前記の分泌腺と同じように局 所免疫機構の存在を示するのであり, 分泌型 IgA が注 目されるにいたつた.

（尿分泌型 IgA の臨床的意義）

尿分泌型 IgA の尿路疾患に打ける臨床的意義につい $\tau$, Uehling \& Steihm ${ }^{4}$ は尿分泌型 IgA は尿路感染症 に対する免疫反応の尺度であると述べている.

Uehling $^{4}$ や Kaufman ${ }^{3)}$ らの成績によれば，尿路感染 症患者は尿分泌型 IgA の特異的な上昇を示した. 尿分 泌型 IgA の平均值は, 感染症例では健康人に比べ約 4 倍とはつきりした有意差があつた.とくに尿路奇型を有 したものが尿路感染を起すと上昇率が高いことも明らか となつた。われわれの成績でも，急性，慢性をとわず 下部尿路感染症では高値を示すものが多く, 感染症以外 の下部尿路疾患ではすべて正常值以下であつた. すなわ ち, 感染とくに膀胼感染症が尿分泌型 IgA 增加をもた らす因子であることが明らかとなつた.

尿路感染症症例でも尿分泌型 IgA が正常值や低值を 示すことがある.われわれの成績でも，同じタイプの膀 胱炎で高值であつたり(一)であつたりした．このことは 局所免疫反応に欠宿があるということではなく，感染の 
重症度が低かつたり，感染の頻度が少ないこと，感染と 尿検査との間隔などの理由によるものだと Uehling() ら は述べている. また逆に, 健康人でも尿分泌型 $\operatorname{IgA}$ が 高值である場合がある. われわれの成績でる軽度上昇を みたものがあつたが，Kaufman ${ }^{3)}$ らは以前に無症候性で 診断不能な感染があつたのではないかと推定している.

尿路感染症の期間や程度によつて尿分泌型 IgA がぞ ら変るかといら問題は，対立した意見があつて明らかで はない，感染の頻度と期間が尿分泌型 IgA の值を決定 づけるといら Uehling4) らの意見と，尿分泌型 IgA 值 は，症状, 期間, 重症度と関联性はないという $\mathrm{Kaufman}^{3)}$ らの意見がある，われわれの成績をみると，急性膀脱炎 群と慢性膀胱炎群との間にはつきりした差はみられなか つたが，慢性群の方が高值を示す割合が高い，膀胱結石 や膀脂秝室があると異常高值を示すといら報告もある が, 今後の問題点となろう。

急性腎孟腎炎で高値を示したものがなからたわれわれ の成績からでは，上部尿路感染症は尿分泌型 $\operatorname{IgA} の$ 增 加と無関係の上うに思克る. しかし，今回の研究目的が 下部尿路であつたため，腎実質障害をともなうような再 発性腎盂腎炎や慢性腎孟腎炎を対象から外したので，上 部尿路感染症と尿分泌型 IgA との関聠性は明らかでは ない. 最近, Smith ${ }^{16)}$ らが家鬼に佂ける実験的腎盂腎炎 腎で分泌型 IgA が新たに合成されたといら報告がある が，Uehling4) らは分泌型 IgA 值の上昇が感染の上部尿 路への波及と関係があるかどうかは不明であると述べて いるので，今後の検討にまちたい．

尿路感染症を除いた下部尿路疾患と尿分泌型 IgA と の関係は，症例数が少ないので結論を差し控えたい，た だ，尿路腫瘍が13例あり，いゔれも尿分泌型 IgA は正 常值以下であつた. 膀胱全体を占める手術不能の進行性 膀胱癌も含まれているので, 膀脂の新生物からは分泌型 IgA の合成はないものと考えている.

（尿 IgA，IgE，IgG，IgM の臨床的意義）

尿路感染症では血清免疫グロブリンが防㮏的役割を果 しているかどうか疑問視されている ${ }^{17)}$ ，尿の免疫グロブ リンについて明らかな相関性は示されていない。

Uehling ${ }^{18)}$ の尿路感染症に打いて血清拈よび尿免疫グ ロブリンがどのような防禦的役割を演じるかを実験的に 調べた. とくに IgG は感染によつて両者とも上昇した が，自然治癒をみたものは感染が残つているものより低 值であつたので，尿 IgG の感染に対する防禦効果はは

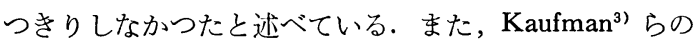

尿路感染児の尿免疫グロブリン検索では，尿 IgG は注 とんどの症例で正常值の上限を越えていたが系球体腎炎 やネフローゼほどではなかつた，われわれの成績をみる と，SLE という特殊な腎疾患を除けば，尿 IgG が高值 であつたものはいづれも炎症性聅患であつた，急性膀胀 炎群の半数，慢性膀腅炎群のほとんどが高值を示してい た.このことは, Hand ${ }^{19)}$ らの実験成績，すなわち下部 尿路感染により膀胱の免疫グロブリン産生は增加し，と くに IgG 合成が著明であつたといら結果に合致してい る.

尿路感染症においては尿 $\operatorname{IgA}$ が分泌型 $\operatorname{IgA}$ ともに 增加する. これは局所性法生成される可能性むあり，米 球体腎炎やネフローゼの著明な増加が血清にその源があ るのと異つていると Uehling4) らは述べている。 しか し，Kaufman ${ }^{3)}$ らの成績では正常群と感染群との間に著 明な差はなかつた．Smifth \& Hand $^{20)}$ の動物実験成績 でも両群とも IgA は存在していた，われわれの成績で も，非常飞高い值を示したものは慢性膀朕炎群と急性腎 盂腎炎群のなかにみられたが，疾患群の間にはつきりし た差が見出せなかつた。また，分必型 IgA と IgA との 関係については，Kaufman ${ }^{3)}$ らは尿路感染症々例では尿 分泌型 IgA 值は尿 IgA 值より高い傾向があり，健康人 症例では低い傾向にあることが観察されたと述べている が，われわれの成績でも同栚な傾向にあつた。

尿 IgM については，健康人㽷には証明されず，尿路 感染症尿にも認められないことが多い. Kauman ${ }^{31}$ らの 成績をみると，尿路感染症17例中僅か 1 例のみ陽性であ つた．IgM は高分子の蛋白であるため，恐らく尿路に は排泄されにくく，系球体基底膜の透過性が異常に充進 したとき出現するとされている，われわれの成績でも少 数例しか検出されなかつた。

尿 $\operatorname{IgE}$ に関する報告はみられない，健康人の血清 IgE はごく微最であるから尿からは検出されないからで あろう。われわれの成績でも，すべて陰性であつた。

\section{結語}

膀腃の局所感染防禦機满を検索する目的で，局所免疫 に関与している分泌型 IgA を尿より検出し，下部尿路 疾患に抢将る尿分泌型 IgA 值を調べ，次の成績を得 た。

（1）念性，慢性をとわず，膀胱炎症例に 尿分泌型 IgA が高值を示すものが多かつた。

（2） 尿路感染症以外の下部尿路疾患症例では，いず れも尿分泌型 IgA は正常值以下であつた. 
（3）急性腎血腎炎症例の尿分泌型 IgA は高値を示 さなかつた。

（4） 尿路腫崵症例の尿分泌型 IgA は高値を示さな からた.

また同時に尿 IgA，IgE，IgG，IgM を測定した. 若干 の尿路感染症々例（とくに慢性膀胱炎）の IgG が高值 を示したものがあつたことを除いて，疾患群の間に有意 差はみられなからた。

これらの成績から，尿分泌型 IgA は膀胱の感染症と 関聠性があることが明らかとなつた。

稿を終るにあたり，分泌型 IgAの Ouchterlony test を おこなつて頂いた金沢大学医学部小児科学教室加藤彰一 博士に感謝いたします。

本諭文の要旨は, 第61回日本泌尿器科学会総会, 第 341 回日本泌尿器科学会東京地方会において発表した。

\section{文献}

1) Cox, C.E. and Hinman, F.: J. Urol., 86, 739, 1961.

2) Pollak, V.E., Gaizutis, M. and Rezaian, J.: J. Lab. Clin. Med., 71, 338, 1968.

3) Kaufman, D.B., Katz, R. and McIntosh, R.M.: Brit Med. J., 4, 463, 1970.

4) Uchling, D.T. and Steihm, E.R.: Pediatrics, 47, 40, 1971.

5) Feldman, B.H., Herdman, R. and Hong, R.: Invest. Urol., 8, 575, 1971.
6) Bienenstock, J. and Tomasi, T.B.: J. Clin. Invest., 47, 1162, 1968.

7) 加藤彰一：日児誌, $47,459,1970$.

8) Salmon, S.E., Mackey, G. and Fundenberg, H.H.: J. Immunol., 103, 129, 1969.

9) Hinman, F. and Cox, C.E.: J. Urol., 96, $491,1966$.

10) Cobbs, C.G. and Kaye, D.: Yale J. Biol. Med., 40, 93, 1967.

11) Gillenwater, J.Y., Cardozo, N.C., Tyrone, N.O., Mulholland, S.G., Hughes, D.G. and Foster, E.A.: J. Urol., 104, 687, 1970.

12) Gregory, J.G., Wein, J.A., Sansone, T.C. and Murphy, J.J.: J. Urol., 105, 220, 1970.

13) Nordon, C.W., Green, G.H. and Kase, E.H.: J. Clin. Invest., 47, 2689, 1968.

14) Tomasi, T.B. and Zigelbaum, S.: J. Clin. Invest., 42, 1552, 1963.

15) Tomasi, T.B., Tan, E.M., Salomon, A. and Prendergast, R.A.: J. Exptl. Med., 121, 101, 1965.

16) Smith, J.W., Hand, W.L. and Sanford, J.P.: J. Immunol., 108, 867, 1972.

17) Buckley, R.H., Dess, S.C. and O'Fallon, W.M.: Pediatrics, 42, 50, 1968.

18) Uehling, D.T.: Invest. Urol., 9, 408, 1972.

19) Hand, W.L., Smith, J.W., Miller, J.E., Barnett, J.A. and Sanford, J.P.: J. Lab. Clin. Med., 75, 20, 1970.

20) Smith, J.W. and Hand, W.L.: J. Immunol., 108, 861, 1971.

（1973年 4 月 9 日受付） 